\title{
Groundnut (Arachis hypogaea L.) growth and yield responses to seed irradiation and mineral fertilization.
}

\author{
${ }^{1}$ Iman A. A. Farag and ${ }^{2}$ Ahmed A. Zahran \\ ${ }^{1,2}$ Natural Products Department, National Center for Radiation Research and Technology, Nasr City ,Cairo, \\ Egypt.
}

\begin{abstract}
A field experiment was conducted in seasons 2009 and 2010 to investigate the effect of low gamma irradiation doses and different mineral fertilization levels on groundnut (Arachis hypogaea L.) vegetative growth and yield. Irradiation doses used in this trial were control, 10, 20 and 30 Gy, nitrogen levels investigated were 30 and $60 \mathrm{Kg} \mathrm{N} / \mathrm{fad}$., and phosphorus and potassium levels investigated were $15.5 \mathrm{P} 2 \mathrm{O} 5+$ $24 \mathrm{~K} 2 \mathrm{O}, 15.5 \mathrm{P} 2 \mathrm{O} 5+48 \mathrm{~K} 2 \mathrm{O}, 31.0 \mathrm{P} 2 \mathrm{O} 5+24 \mathrm{~K} 2 \mathrm{O}$ and $31.0 \mathrm{P} 2 \mathrm{O} 5+48 \mathrm{~K} 2 \mathrm{O} \mathrm{Kg} \mathrm{N/fad}$. Results reveal that all radiation doses enhanced vegetative growth and yield parameters. Moreover, mineral fertilization significantly affected plant height, leaf area, leaf area index and shelling percentage, number of pods and seeds, seed oil and protein \%. All recorded traits improved significantly with increasing fertilization levels.
\end{abstract}

Key words: groundnut (Arachis hypogaea L.), gamma irradiation, mineral fertilization, seed yield.

\section{Introduction}

Groundnut [Peanut] (Arachis hypogaea L.) is one of the world's most popular oil seed crops which is grown as an annual plant but perennial growth is possible in climates which are warm until harvest. It is best cultivated in well drained sandy or sandy loam soils with $\mathrm{pH}$ ranging from 5.5 to 6.5 . Its high content of oil and protein makes it an important commodity for both human use and livestock feed. Moreover, shells are sometimes used as fuel, for the generation of electricity.

Although, excessive use of mineral fertilizers negatively affects soil environment and reduces profit margins farmers gain, it occurs to boost crop production to meet the increasing demands of consumers. Optimization of mineral fertilization is the key for optimizing groundnut production, as it has very high nutrient requirements. Contrarily, severe mineral nutrient deficiencies due to inadequate and imbalanced use of nutrients is one of the major factors responsible for low yield ${ }^{[\mathrm{l}}$ (Kabir et al., 2013). The productivity of groundnut depends on proper selection of variety, fertilizer management and other management practices ${ }^{\text {[D }}$ (Lourduraj, 1999).

Nitrogen $(\mathrm{N})$ is required by plants in comparatively larger amounts than other elements, some of which comes from biological nitrogen fixation and the rest is added as a fertilizer. Other nutrients plants need such as phosphorus, calcium and other elements are also needed for good seed formation '(Asiedu et al., 2000). Phosphorus $(\mathrm{P})$ is the second major essential nutrient element for crop growth and good quality yield with the most obvious effect on the plant root system. The requirement of $\mathrm{P}$ in nodulating legumes is higher compared to non-nodulating crops as it plays a significant role in nodule formation and fixation of atmospheric nitrogen ${ }^{\square}$ (Brady and Well, 2002).

Groundnut seeds are mainly comprised of protein, fat and carbohydrate and that is what make it sensitive to radiation induced stress, but unlike the suppressive effect high gamma rays ( $0.7-2.3 \mathrm{KGy}$ ) have on germination and growth parameters of groundnut ${ }^{\mathrm{D}}$ (Aparna et al., 2013), low doses have been reported to be beneficial ${ }^{[]}$Lukanda et al., (2013). 'Error! Bookmark not defined. ${ }^{]}$Lukanda et al. ( 2013) stated that gamma rays produce radicals that can damage and affect differentially plant morphology, anatomy, biochemistry, and physiology depending on the irradiation level. They added that lower exposures to gamma rays were sometimes stimulatory and that several studies reported improvement of agronomic characteristics by using gamma radiation.

This study was carried out to study the possibility of reducing mineral fertilization levels and coupling it with irradiating seeds with low gamma doses that has been reported to promote growth of several plants aiming at compensating the expected negative effect resulting from reduced fertilization levels.

\section{Materials and Methods}

Two field trials were carried out in the two successive summer seasons of 2009 and 2010 in an experimental field in Belbaise, Sharkia Governorate, Egypt, to study the effect of low gamma radiation doses and reduced NPK fertilizer levels on vegetative growth, yield attributes and protein content in cv. Giza 6 groundnut plants. 
1.1. Treatments:

1.1.1. Nitrogen fertilizer levels (main plot) under experiment were either 30 or $60 \mathrm{~kg} \mathrm{~N} /$ fad., in the form of Ammonium sulphate $(20.6 \% \mathrm{~N})$. Quantities were divided into three equal portions and applied at sawing, a month latter and 50 days from plantation.

1.1.2. Gamma irradiation doses (sub- plot) of $0,10,20$ and $30 \mathrm{~Gy}$ were investigated in this trial, and were applied via a self-contained dry-storage gamma irradiator with caesium-137 as a radiation source.

1.1.3. Phosphorus and potassium fertilizers (sub- sub- plot) were added in the form of calcium super phosphate $\left(15.5 \% \mathrm{P}_{2} \mathrm{O}_{5}\right)$ and potassium sulphate $\left(48 \% \mathrm{~K}_{2} \mathrm{O}\right)$ at four different levels, i.e.; $15.5 \mathrm{P}_{2} \mathrm{O}_{5}+24 \mathrm{~K}_{2} \mathrm{O}$ $\mathrm{kg} / \mathrm{fad}, 15.5 \mathrm{P} 2 \mathrm{O} 5+48 \mathrm{~K} 2 \mathrm{O} \mathrm{kg} / \mathrm{fad}, 31 \mathrm{P}_{2} \mathrm{O}_{5}+24 \mathrm{~K}_{2} \mathrm{O} \mathrm{kg} /$ fad and $31 \mathrm{P}_{2} \mathrm{O}_{5}+48 \mathrm{~K} 2 \mathrm{O} \mathrm{kg} /$ fad. The phosphorus fertilizer was added during seed bed preparation and the potassium fertilizer was added at plantation.

Gypsum was added to the soil during seed bed preparation at the rate of $750 \mathrm{~kg} / \mathrm{fad}$ and the seeds were sown in hills, $10 \mathrm{~cm}$ apart, on ridges in on mid-May in both seasons. Normal cultural practices for groundnut were applied as recommended all through the growing season, and latter, manual harvest was on mid-September.

Vegetative characteristics recorded in this study were plant height $(\mathrm{cm})$, number of branches/ plant and number of pods/ plant. As for the leaf area, it was measured at three stages, 75, 90 and 105 days from planting, and it was determined using the disk method according to Johanson (1967). Leaf area index (LAI) was calculated according to ${ }^{[]}$Radford (1967) formula

Leaf area index $($ LAI $)=\frac{(\text { leaf area/ plant })(\mathrm{cm})^{2}}{(\text { land area/ plant })(\mathrm{cm})^{2}}$

Yield attributes studied in this trial were the number of seeds/ 100 pods, pod weight/ plant (g), seed weight/ plant (g), weight of 100 seeds (g), pod yield was recorded after thorough drying (kg/ Fed), seed yield (kg/ fad), straw yield (Ton/ fad), biological yield (Ton/ Fed), oil content (\%) was estimated by Soxhlet Ether Extract method II (A.O.A.C., 2002) or (using nucleic magnetic resonance NMR), oil yield (kg/ Fed) and protein percentage $(\%)$.

$\frac{\text { Weight of seeds }(\mathrm{g})}{\text { Weight of pods }} \times 100$

The experiment was laid out in a factorial arrangement (2 nitrogen fertilizer levels) $\mathrm{x}$ (4 gamma irradiation doses) $\mathrm{x}$ ( 4 phosphorus and potassium fertilizer levels) in a randomized complete block design where each experimental unit (plot) contained 5 ridges, $4 \mathrm{~m}$ long and $60 \mathrm{~cm}$ apart. All the data was analyzed by analysis of variance (ANOVA) which is the procedure used for testing the differences between the means of two or more treatment, and the differences between means were detected using least significant difference (L.S.D.) P $<0.05$ according to ${ }^{[\mathrm{G}} \mathrm{Gomez}$ and Gomez (1984). Results for the main treatments only are presented and discussed in this study.

\section{Results and Discussion}

As shown in Tables (1- 7), gamma irradiation, $\mathrm{N}$ and PK fertilizer levels significantly affected all characteristics under investigation (except for protein (\%) that was insignificantly affected by gamma irradiation and PK fertilizer levels). Results presented in Table 1 show that increases in gamma irradiation dose, N and PK fertilizer levels were always correlated with increases in plant height, with exception when the irradiation dose raised from 10 to $20 \mathrm{~Gy}$ in season 2009. It was also noticed that with the application of $15.5 \mathrm{Kg} \mathrm{P} / \mathrm{fad}$., increasing K levels from 24 to $48 \mathrm{Kg} /$ fad., resulted insignificant increases in plant height in both seasons.

Results also revealed that, with except for increasing the irradiation dose from 10 to $20 \mathrm{~Gy}$ in season 2010, all increments in radiation doses, $\mathrm{N}$ and PK fertilizer levels, were correlated with significant increases in number of branches/ plant. In this regard, ${ }^{[]}$Salve and Gunjal (2011) reported that the application of 50 and $75 \mathrm{~kg}$ $\mathrm{P} 2 \mathrm{O} 5$, as well as 30 and $45 \mathrm{~kg} \mathrm{~K} 2 \mathrm{O} /$ ha to groundnut were at par with each other but significantly increased plant height and spread compared to the application of $25 \mathrm{~kg} \mathrm{P} 2 \mathrm{O}$, and 30 and $45 \mathrm{~kg} \mathrm{~K} 2 \mathrm{O} /$ ha, respectively. That are also in agreement with results of ${ }^{[0}$ Gobarah et al. (2006) who reported an increase in vegetative growth when P levels was increased from 30 to $60 \mathrm{Kg} \mathrm{P} /$ fad. Similarly, number of pods/ plant recorded significant increases as a result of increasing irradiation dose and $\mathrm{N}$ fertilizer level. In this regard, it is worth mentioning that a variety named JL24 recorded a $37 \%$ increase in the number of pods/ plant in response to a $100 \mathrm{~Gy}$ dose Error! Bookmark not defined. ${ }^{]}$(Lukanda,et al., 2013). On the other hand, it was found that doubling $\mathrm{K}$ application levels with the application of $31 \mathrm{~kg} \mathrm{P} /$ fad., resulted in insignificant increases in the number of pods/ plant in both seasons under investigation. In this regard, ${ }^{[]}$Shiyam (2010) reported that, different phosphorus levels insignificantly affected plant height and number of branches/ plant while it significantly affected the number of filled pods/ plants, with $40 \mathrm{~kg}$ P2O5/ ha recording the best result. 
Such results are in agreement with results reported by ${ }^{[}$Error! Bookmark not defined. ${ }^{]}$Kabir et al. (2013) regarding significant increases in plant height and number of branches/ plant in response to increasing $\mathrm{P}$ fertilization levels from 0 to 25 and from 25 to $50 \mathrm{~kg}$ P/ ha. Similar results have been reported by ${ }^{[]}$Sharma and Yadav (1997) and [] Rahman (2006). The increases in plant growth due to P application may be attributable to the role of phosphorus in the development of more extensive root system 'Error! Bookmark not defined. ${ }^{]}$(Sharma and Yadav 1997 and ${ }^{[}$Error! Bookmark not defined. ${ }^{]}$Gobarah et al., 2006) and enhanced nodulation, and thus enables plants to absorb more water and nutrients from of the soil, which is reflected afterwards in the form of vegetative growth.

In this regard, ${ }^{[}$Aparna et al. (2013) clearly revealed that the sensitivity of groundnut crop to gamma radiation stress beyond $0.70 \mathrm{kGy}$ can be accepted as a threshold level of radiation stress and determined 1.50 $\mathrm{kGy}$ as the LD value for groundnut. Unlike results in this study in response to low dose gamma irradiation, decreased shoot length of groundnut [Error! Bookmark not defined.](Aparna et al., 2013) and a number of crops such as cowpea ${ }^{[]}$(Thimmaiah et al., 1998) and long bean ${ }^{[]}$(Kon et al., 2007) has already been reported earlier in response to higher irradiation doses. In addition, high doses of gamma irradiation were reported to be harmful in several studies like that of ${ }^{\prime}$ Error! Bookmark not defined. ${ }^{l}$ Lukanda et al. (2013) on groundnut and ${ }^{[}$Ramachandran and Goud (1983), who reported that higher doses of gamma irradiation reduced plant height, number of leaves and branching capacity of safflower. ${ }^{[]}$Kiong et al. (2008) reported that radiation caused reduction in endogenous growth regulators, especially cytokinins, as a result of break down, or lack of synthesis and noticed that treating seeds with high rates of gamma radiation reduced germination with a corresponding decline in plant growth. ${ }^{[l}$ Shakoor et al. (1978) attributed decreased shoot and root lengths at higher doses of gamma rays to reduced mitotic activity in meristamatic tissues. On the other hand, positive effects of low doses of gamma rays irradiation on plant growth may be due to the stimulation of cell division or elongation, or the alteration of metabolic processes that affect the synthesis of phytohormones or nucleic acids ${ }^{[\amalg]}$ (Pitirmovae, 1979 and Hanan et al., 2011).

On the other hand, Leaf area data presented in table 2 followed a stable pattern of significant increments that occurred as a result of increasing the irradiation dose, $\mathrm{N}$ and PK fertilizer levels applied.

As shown in Table 3, LAI increases after 75, 90 and 105 days after planting as a result of increasing radiation dose and $\mathrm{N}$ fertilizer levels in both seasons under investigation. As for the effect of PK fertilization on LAI after 75 days, each increase in P or $\mathrm{K}$ was correlated with a significant increase in LAI. Later, after 90 days, increases of LAI were significant when $\mathrm{P}$ was doubled. On the other hand, doubling the $\mathrm{K}$ level with the lower $\mathrm{P}$ level in season 2009, only resulted in a significant increase in LAI .After 105 days from sowing, increasing the $\mathrm{P}$ fertilizer levels only resulted in significant increases in LAI in both seasons, while $\mathrm{K}$ was of a minor effect. Here, it is worth mentioning that 'Error! Bookmark not defined.' Salve and Gunjal (2011) reported that uptake of $\mathrm{N}, \mathrm{P}$ and $\mathrm{K}$ significantly increased with the increased levels of potassium fertilization, which might explain the enhanced vegetative growth that occurred in response to increased $\mathrm{K}$ quantities.

Table 4 shows that irradiating groundnut seeds with 10,20 and 30 Gy resulted in 13.8, 17.5 and $23.9 \%$ increases in the number of seeds/ 100 pods compared to the control in season 2009 and 12.9, 18.6 and $25.2 \%$ increases in the latter season. Similarly, significant increases were recorded in both seasons as a result of increasing $\mathrm{N}$ from 30 to $60 \mathrm{Kg} \mathrm{N} /$ fad. As for the effect of P and $\mathrm{K}$ fertilization levels on the number of seeds/ 100 pods, doubling quantities of either mineral, resulted in significant increases in values recorded. Pod weight/ plant and seed weight/ plant values shown in the same Table, follow an almost similar trend, were increases in radiation doses and $\mathrm{N}$ quantity resulted in significant increases in records. The only detected insignificant increase was recorded in season 2010 for the pod weight/ plant when the irradiation dose was increased from 10 to $20 \mathrm{~Gy}$. In this regard, it was found that increasing the P and K levels from 15.5 and 24 to 31 and 48 P2O5 and $\mathrm{K} 2 \mathrm{O}$, respectively led to significant increases in pod weight/ plant and seed weight/ plant in both seasons under investigation.

As shown in Table 5, each increase in gamma dose, $\mathrm{N}$ and PK fertilization rate was correlated with a significant increase in the weight of 100 seeds and pod yield. This trend persisted in shelling (\%), but irradiation showed a slight deviation, 10 Gy significantly increased shelling (\%)but differences between consecutive doses proved to be insignificant. Such results are in harmony with results of ${ }^{[}$Error! Bookmark not defined. ${ }^{\text {Kabir }}$ et al. (2013) who reported that $50 \mathrm{~kg} \mathrm{P} /$ ha led to significant increases in 100 pods weight and shelling (\%) compared to control ( $0 \mathrm{~kg} / \mathrm{ha}$ ), while $25 \mathrm{~kg} \mathrm{P} /$ ha resulted in a significant increase in shelling (\%) only, compared to control. They are also in agreement with the results of ${ }^{[]}$Ibrahim and Eleiwa (2008) who reported that doubling NPK levels from (30:30:25) to (60:60:50) significantly increased weight of 100 seeds, shelling $(\%)$ and weight of pods $\left(\mathrm{Kg} / \mathrm{fad}\right.$.). Obtained results are in full agreement with those reported by ${ }^{[]}$ Nasr- Alla et al. (1998),[] El-Far and Ramadan (2000), ${ }^{[]}$Laxminarayana (2004) and ${ }^{[]}$Hossain et al. (2007), who reported that increasing NPK rate as a single of in combination application has a beneficial effect on groundnut yield attributes. They attributed the significant increase of number of pods/ plant, weight of 100 seeds and seed 
yield to the application of NP and added that NP application at $60: 60 \mathrm{~kg} /$ fad., resulted in the best morphological characteristics which eventually led to greater pod yield. They added that further increase of $\mathrm{N}$ and $\mathrm{P}$ levels beyond $60 \mathrm{Kg} /$ fad., for each element, tended to depress $\mathrm{N}$ and $\mathrm{P}$ uptake, number of pods/ plant, 100 seed weight and pod yield.

Results are also in accordance with that of ${ }^{[l]}$ Patra et al., (1995) reported regarding the increased pod yield and root- shoot ratio as a result of $\mathrm{N}$ addition. Nitrogen is known to be an important determinant of plant growth and development, and this might explain the increased yield in response to increased $\mathrm{N}$ application.

As shown in Table 6, seed yield recorded significant increases with each increases in radiation dose, $\mathrm{N}$ and PK application rate. Such effect was also noticed in straw and biological yields in response to increments in radiation doses and $\mathrm{N}$ fertilizer levels In this regard, 'Error! Bookmark not defined.'Lukanda et al. (2013) reported that gamma irradiation dose of $100 \mathrm{~Gy}$ resulted in a $62 \%$ increase in the number of seeds/ plant and in a $14 \%$ increase in grain yield for wheat variety called JL24, while JG12 variety recorded an $8 \%$ increase in the number of seeds/ plant, compared to unirradiated seeds. And in another study, ${ }^{[]}$Mudibu et al. (2010) reported the highest grain yield increase in soybean was achieved via a 200 Gy irradiation dose.

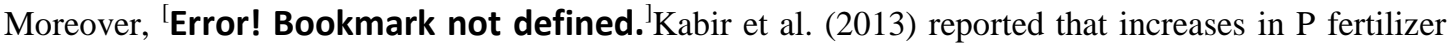
levels were correlated with significant increases in straw and biological yields ( $\mathrm{kg} / \mathrm{ha}$.). 'Error! Bookmark not defined. ${ }^{]}$Shiyam (2010) also, reported that groundnut seed yield significantly increased when 30 and $40 \mathrm{~kg}$ P2O5/ ha were applied. They recorded reduced seed yield in plots fertilized with $50 \mathrm{~kg}$ P2O5/ha and stated that it might be a reflection of the suppressive effect of phosphorus on pod filling,. Moreover ${ }^{[]}$Udom et al. (2003) documented a positive relationship between pod filling and seed yield in groundnut.

As for the effect of PK application levels, it was noticed that straw and biological yields showed significant increases when $\mathrm{P}$ or K levels were doubled but insignificant differences between 15.5 P2O +48 $\mathrm{K} 2 \mathrm{O}$ and $31 \mathrm{P} 2 \mathrm{O} 5+24 \mathrm{~K} 2 \mathrm{O}$ were recorded for both characteristics in both seasons under investigation.

Such result was unlike to the results reported by 'Error! Bookmark not defined. 'Shiyam (2010) who found that different phosphorus levels insignificantly affected dry biomass. On the other hand, our results are consistent with the results reported by 'Error! Bookmark not defined.'Ibrahim and Eleiwa (2008) regarding significantly increase in both straw and seed yields in response to doubling NPK fertilizer levels. Our results are also supported by the findings of ${ }^{[}$Error! Bookmark not defined. ${ }^{1}$ Gobarah et al. (2006) who reported increased yield and yield components and improved seed quality in response to increasing P levels from 30 to $60 \mathrm{Kg} / \mathrm{Fed}$. Such increases might be due to the increase in phosphorus levels which is known to help in developing extensive root system that helps the plant in absorbing water and nutrients efficiently, which in turn enhances the plant to produce more assimilates which was reflected in higher biomass. 'Error! Bookmark not defined. ${ }^{]}$Kabir et al. (2013) also stated that it might be attributed to its role in activating the metabolic processes and contributing in building phospholipids and nucleic acid. Moreover $\mathrm{P}$ is an important nutrient for all the crops in general and legumes in particular and takes a part in the production of ATP ${ }^{\mathrm{U}}$ (Malavolta et al., 1997) and plays a significant role in energy transformation in plant and in seed formation. Moreover, Potassium is known for its ability to increase yield and improve quality. It also plays an essential role in photosynthesis and pod development in groundnut ${ }^{[]}$(Burkhart and Collins, 1941).

As presented in Table 7, seed oil content recorded significant increases in response to factors under investigation and it was noticed that the 20 and 30 Gy treatments in season 2009 and the 10 and $20 \mathrm{~Gy}$ treatments in the latter season showed insignificant differences in between. Significance was also detected with each increase in mineral fertilizer levels. Similarly, oil yield recorded significant increases with increments in N and PK fertilizer levels. Moreover, significant increases in oil yield were recorded in response to increasing irradiation doses in both seasons, though, 10 and $20 \mathrm{~Gy}$ showed an insignificant difference in- between in season 2010 only. As for the protein content (\%), only raising N fertilization rate from 30 to $60 \mathrm{Kg} \mathrm{N} /$ fad., led to a significant increase in protein (\%). In this regard, 'Error! Bookmark not defined. ${ }^{1}$ Salve and Gunjal (2011) stated that the application of potassium did not influence yield attributes (dry pod and haulm yields and protein

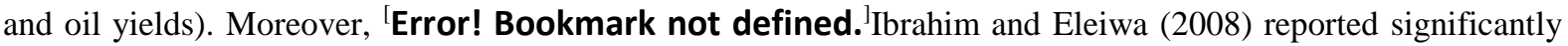
high oil and protein (\%) values in groundnut seeds when NPK were applied at a rate of 60:60:50 Kg/ fad., compared to 30:30:25 Kg/ fad. They stated that this might be due to the enhanced absorbion of nutrients from the soil solution resulting from their abundance when higher fertilization rates were applied, and hence promoted better assimilation leading to higher oil and protein content. Moreover, higher oil yield/ hectare and unaltered seed oil content were recorded for Crambe abssynica Hoechst (an oilseed crop belonging to the Brassicaceae family, with high oil content, and thus a material for biodiesel production) as a result of increasing P2O5 ${ }^{\square}$ (Rogério et al., 2013). Significant increases in protein and oil content in kernels in response to increasing $\mathrm{K}$ rate from 15 to 30 and $45 \mathrm{~kg} \mathrm{~K} 2 \mathrm{O} /$ ha has been reported earlier by [Error! Bookmark not defined.]Salve and Gunjal (2011).On the other hand, our findings contradict those obtained by ${ }^{[l}$ El-Habbasha et al. (2005) and 
[Error! Bookmark not defined. ${ }^{]}$Gobarah et al. (2006) who reported a significant increase in protein content when $\mathrm{P}$ application rate was increased from 30 to $60 \mathrm{Kg} /$ fad., while statistical significance was not detected in the oil content increase.

Phosphorus has also been reported to be an important nutrient for all crops in general and legumes in particular, since it is a key constituent of ATP and plays a significant role in energy transformation in plant and also plays various roles in seed formation ${ }^{[]}$(Sanker et al., 1984). Moreover, increased yields due to phosphorus fertilizers might be attributed to its role in building phospholipids and nucleic acids and hence activating the metabolic process ${ }^{[]}$(Marschner, 1986). It also stimulates root formulation, growth, increases nitrogen fixation'More et al. 2002), aids in nodule formation, and increases the protein and mineral content in groundnut kernel.

IV. Figures and Tables

Table (1): Effect of irradiation and different mineral fertilizer levels on plant height (cm), number of branches/ plant and number of pods/ plant.

\begin{tabular}{|c|c|c|c|c|c|c|c|c|c|}
\hline \multirow{2}{*}{ Main effects } & \multicolumn{3}{|c|}{ Plant height (cm) } & \multicolumn{3}{|c|}{ Number of branches/plant } & \multicolumn{3}{|c|}{ Number of pods/ plant } \\
\hline & 2009 & 2010 & Combined & 2009 & 2010 & Combined & 2009 & 2010 & Combined \\
\hline \multicolumn{10}{|c|}{ Gamma irradiation (Gy) } \\
\hline $\mathbf{0}$ & 60.00 & 61.34 & 60.67 & 8.18 & 8.59 & 8.39 & 21.23 & 22.11 & 21.67 \\
\hline 10 & 63.03 & 63.65 & 63.34 & 8.94 & 9.98 & 9.46 & 23.42 & 24.33 & 23.88 \\
\hline 20 & 65.05 & 66.49 & 65.77 & 9.99 & 10.64 & 10.32 & 25.26 & 25.96 & 25.61 \\
\hline 30 & 69.11 & 70.79 & 69.95 & 11.9 & 13.12 & 12.51 & 27.09 & 27.76 & 27.43 \\
\hline $\operatorname{LSD}(5 \%)$ & 2.21 & 2.11 & 2.15 & 0.73 & 0.88 & 0.69 & 0.93 & 0.87 & 1.01 \\
\hline \multicolumn{10}{|c|}{ Nitrogen fertilizer (Kg N/ fad.) } \\
\hline 30 & 62.63 & 64.19 & 63.41 & 8.22 & 9.1 & 8.66 & 23.40 & 23.88 & 23.64 \\
\hline 60 & 65.96 & 66.93 & 66.45 & 11.28 & 12.06 & 11.67 & 25.10 & 26.19 & 25.65 \\
\hline LSD $(5 \%)$ & 2.03 & 2.07 & 1.90 & 1.12 & 1.15 & 1.23 & 1.32 & 1.25 & 1.17 \\
\hline \multicolumn{10}{|c|}{ Phosphorus and potassium fertilizers ( $\mathrm{Kg} /$ fad.) } \\
\hline $15.5 \mathrm{P}_{2} \mathrm{O}_{5}+24 \mathrm{~K}_{2} \mathrm{O}$ & 59.15 & 60.11 & 59.63 & 8.59 & 8.96 & 8.78 & 21.68 & 21.93 & 21.81 \\
\hline $15.5 \mathrm{P}_{2} \mathrm{O}_{5}+48 \mathrm{~K}_{2} \mathrm{O}$ & 61.05 & 62.09 & 61.57 & 9.21 & 9.65 & 9.43 & 23.76 & 24.96 & 24.36 \\
\hline $31 \mathrm{P}_{2} \mathrm{O}_{5}+24 \mathrm{~K}_{2} \mathrm{O}$ & 66.59 & 68.53 & 67.56 & 9.75 & 11.14 & 10.45 & 24.94 & 26.11 & 25.53 \\
\hline $31 \mathrm{P}_{2} \mathrm{O}_{5}+48 \mathrm{~K}_{2} \mathrm{O}$ & 70.4 & 71.55 & 70.98 & 11.45 & 12.58 & 12.02 & 26.63 & 27.17 & 26.90 \\
\hline LSD $(5 \%)$ & 2.35 & 2.17 & 2.21 & 0.31 & 0.11 & 0.23 & 1.73 & 1.66 & 1.68 \\
\hline
\end{tabular}

Table (2): Effect of irradiation and different mineral fertilizer levels on leaf area (cm2) at 75, 90 and 105 days from planting.

\begin{tabular}{|c|c|c|c|c|c|c|c|c|c|}
\hline \multirow{2}{*}{ Main effects } & \multicolumn{3}{|c|}{ Leaf area $\left(\mathrm{cm}^{2}\right)$ at 75 days } & \multicolumn{3}{|c|}{ Leaf area $\left(\mathrm{cm}^{2}\right)$ at 90 days } & \multicolumn{3}{|c|}{ Leaf area $\left(\mathrm{cm}^{2}\right)$ at 105 days } \\
\hline & 2009 & 2010 & Combined & 2009 & 2010 & Combined & 2009 & 2010 & Combined \\
\hline \multicolumn{10}{|c|}{ Gamma irradiation (Gy) } \\
\hline $\mathbf{0}$ & 488.11 & 614.65 & 551.38 & 632.73 & 714.08 & 673.47 & 759.28 & 921.98 & 840.63 \\
\hline 10 & 614.65 & 714.08 & 664.43 & 677.93 & 822.55 & 750.24 & 903.90 & 1156.99 & 1030.45 \\
\hline 20 & 741.20 & 813.51 & 777.35 & 858.71 & 1093.72 & 976.21 & 1102.76 & 1265.46 & 1184.11 \\
\hline 30 & 903.90 & 921.98 & 912.94 & 958.13 & 1129.88 & 1044.07 & 1328.73 & 1373.93 & 1351.40 \\
\hline $\operatorname{LSD}(5 \%)$ & 24.36 & 36.21 & 33.99 & 16.54 & 13.21 & 17.55 & 27.65 & 23.21 & 26.84 \\
\hline \multicolumn{10}{|c|}{ Nitrogen fertilizer (Kg N/ fad.) } \\
\hline 30 & 596.57 & 668.89 & 632.73 & 705.04 & 876.78 & 790.98 & 985.25 & 1066.60 & 1025.99 \\
\hline 60 & 777.35 & 849.67 & 813.51 & 858.71 & 1003.33 & 931.02 & 1057.56 & 1292.58 & 1175.07 \\
\hline $\operatorname{LSD}(5 \%)$ & 28.31 & 27.64 & 23.27 & 7.65 & 8.93 & 8.87 & 12.27 & 13.37 & 13.14 \\
\hline \multicolumn{10}{|c|}{ Phosphorus and potassium fertilizers (Kg/ fad.) } \\
\hline $\begin{array}{c}15.5 \mathrm{P}_{2} \mathrm{O}_{5}+24 \\
\mathrm{~K}_{2} \mathrm{O}\end{array}$ & 524.26 & 587.54 & 555.96 & 587.54 & 822.55 & 705.04 & 967.17 & 1102.76 & 1035.03 \\
\hline $\begin{array}{c}15.5 \mathrm{P}_{2} \mathrm{O}_{5}+48 \\
\mathrm{~K}_{2} \mathrm{O}\end{array}$ & 632.73 & 705.04 & 668.89 & 677.93 & 867.74 & 772.90 & 985.25 & 1120.84 & 1053.11 \\
\hline $\begin{array}{c}31 \mathrm{P}_{2} \mathrm{O}_{5}+24 \\
\mathrm{~K}_{2} \mathrm{O} \\
\end{array}$ & 759.28 & 822.55 & 790.98 & 903.90 & 1003.33 & 953.68 & 1057.56 & 1238.34 & 1147.95 \\
\hline $\begin{array}{c}31 \mathrm{P}_{2} \mathrm{O}_{5}+48 \\
\mathrm{~K}_{2} \mathrm{O} \\
\end{array}$ & 858.71 & 940.06 & 899.45 & 940.06 & 1066.60 & 1003.33 & 1075.64 & 1256.42 & 1166.03 \\
\hline $\operatorname{LSD}(5 \%)$ & 21.30 & 23.51 & 28.58 & 15.34 & 17.92 & 14.03 & 12.01 & 11.99 & 12.05 \\
\hline
\end{tabular}


Groundnut (Arachis hypogaea L.) growth and yield responses to seed irradiation and ....

Table (3): Effect of irradiation and different mineral fertilizer levels on leaf area index (LAI) at 75, 90 and 105 days from planting.

\begin{tabular}{|c|c|c|c|c|c|c|c|c|c|}
\hline \multirow{2}{*}{ Main effects } & \multicolumn{3}{|c|}{ LAI at 75 days } & \multicolumn{3}{|c|}{ LAI at 90 days } & \multicolumn{3}{|c|}{ LAI at 105 days } \\
\hline & 2009 & 2010 & Combined & 2009 & 2010 & Combined & 2009 & 2010 & Combined \\
\hline \multicolumn{10}{|l|}{ Gamma irradiation (Gy) } \\
\hline 0 & 1.22 & 1.54 & 1.38 & 1.58 & 1.79 & 1.68 & 1.90 & 2.30 & 2.10 \\
\hline 10 & 1.54 & 1.79 & 1.66 & 1.69 & 2.06 & 1.88 & 2.26 & 2.89 & 2.58 \\
\hline 20 & 1.85 & 2.03 & 1.94 & 2.15 & 2.73 & 2.44 & 2.76 & 3.16 & 2.96 \\
\hline 30 & 2.26 & 2.30 & 2.28 & 2.40 & 2.82 & 2.61 & 3.32 & 3.43 & 3.38 \\
\hline $\operatorname{LSD}(5 \%)$ & 0.03 & 0.04 & 0.03 & 0.02 & 0.01 & 0.02 & 0.03 & 0.03 & 0.03 \\
\hline \multicolumn{10}{|c|}{ Nitrogen fertilizer (Kg N/ fad.) } \\
\hline 30 & 1.49 & 1.67 & 1.58 & 1.76 & 2.19 & 1.98 & 2.46 & 2.67 & 2.56 \\
\hline 60 & 1.94 & 2.12 & 2.03 & 2.15 & 2.51 & 2.33 & 2.64 & 3.23 & 2.94 \\
\hline $\operatorname{LSD}(5 \%)$ & 0.03 & 0.03 & 0.03 & 0.01 & 0.01 & 0.01 & 0.01 & 0.01 & 0.01 \\
\hline \multicolumn{10}{|c|}{ Phosphorus and potassium fertilizers (Kg/ fad.) } \\
\hline $15.5 \mathrm{P}_{2} \mathrm{O}_{5}+24 \mathrm{~K}_{2} \mathrm{O}$ & 1.31 & 1.47 & 1.39 & 1.47 & 2.06 & 1.76 & 2.42 & 2.76 & 2.59 \\
\hline $15.5 \mathrm{P}_{2} \mathrm{O}_{5}+48 \mathrm{~K}_{2} \mathrm{O}$ & 1.58 & 1.76 & 1.67 & 1.69 & 2.17 & 1.93 & 2.46 & 2.80 & 2.63 \\
\hline $31 \mathrm{P}_{2} \mathrm{O}_{5}+24 \mathrm{~K}_{2} \mathrm{O}$ & 1.90 & 2.06 & 1.98 & 2.26 & 2.51 & 2.38 & 2.64 & 3.10 & 2.87 \\
\hline $31 \mathrm{P}_{2} \mathrm{O}_{5}+48 \mathrm{~K}_{2} \mathrm{O}$ & 2.15 & 2.35 & 2.25 & 2.35 & 2.67 & 2.51 & 2.69 & 3.14 & 2.92 \\
\hline $\operatorname{LSD}(5 \%)$ & 0.07 & 0.08 & 0.05 & 0.03 & 0.07 & 0.05 & 0.04 & 0.05 & 0.02 \\
\hline
\end{tabular}

Table (4): Effect of irradiation and different mineral fertilizer levels on number of seeds/ 100 pods, pod weight/ plant (g) and seed weight/ plant (g).

\begin{tabular}{|c|c|c|c|c|c|c|c|c|c|}
\hline \multirow{2}{*}{ Main effects } & \multicolumn{3}{|c|}{ Number of seeds/ 100 pods } & \multicolumn{3}{|c|}{ Pod weight/plant (g) } & \multicolumn{3}{|c|}{ Seed weight/ plant (g) } \\
\hline & 2009 & 2010 & Combined & 2009 & 2010 & Combined & 2009 & 2010 & Combined \\
\hline \multicolumn{10}{|c|}{ Gamma irradiation (Gy) } \\
\hline $\mathbf{0}$ & 127.96 & 130.65 & 129.31 & 36.11 & 36.86 & 36.49 & 22.24 & 22.92 & 22.58 \\
\hline 10 & 145.58 & 147.52 & 146.55 & 40.20 & 40.77 & 40.49 & 24.63 & 25.51 & 25.07 \\
\hline 20 & 150.3 & 154.91 & 152.61 & 41.29 & 42.49 & 41.89 & 28.74 & 28.94 & 28.84 \\
\hline 30 & 158.48 & 163.56 & 161.02 & 43.19 & 44.50 & 43.85 & 31.54 & 31.93 & 31.74 \\
\hline LSD (5\%) & 3.36 & 4.22 & 4.11 & 1.03 & 1.73 & 1.53 & 2.33 & 2.11 & 2.2 \\
\hline \multicolumn{10}{|c|}{ Nitrogen fertilizer (Kg N/ fad.) } \\
\hline 30 & 141.42 & 143.89 & 142.66 & 39.23 & 39.93 & 39.58 & 25.39 & 25.67 & 25.53 \\
\hline 60 & 149.72 & 154.43 & 152.08 & 41.16 & 42.38 & 41.77 & 28.18 & 28.98 & 28.58 \\
\hline $\operatorname{LSD}(5 \%)$ & 4.53 & 4.11 & 4.77 & 1.34 & 2.11 & 2.01 & 2.93 & 2.64 & 2.81 \\
\hline \multicolumn{10}{|c|}{ Phosphorus and potassium fertilizers (Kg/ fad.) } \\
\hline $15.5 \mathrm{P}_{2} \mathrm{O}_{5}+24 \mathrm{~K}_{2} \mathrm{O}$ & 137.11 & 140.08 & 138.60 & 38.23 & 39.05 & 38.64 & 22.86 & 21.92 & 22.39 \\
\hline $15.5 \mathrm{P}_{2} \mathrm{O}_{5}+48 \mathrm{~K}_{2} \mathrm{O}$ & 141.52 & 148.16 & 144.84 & 39.25 & 40.92 & 40.09 & 24.75 & 25.32 & 25.04 \\
\hline $31 \mathrm{P}_{2} \mathrm{O}_{5}+24 \mathrm{~K}_{2} \mathrm{O}$ & 147.63 & 150.3 & 148.97 & 40.67 & 41.42 & 41.05 & 27.88 & 29.5 & 28.69 \\
\hline $31 \mathrm{P}_{2} \mathrm{O}_{5}+48 \mathrm{~K}_{2} \mathrm{O}$ & 156.03 & 158.1 & 157.07 & 42.62 & 43.23 & 42.93 & 31.76 & 32.56 & 32.16 \\
\hline $\operatorname{LSD}(5 \%)$ & 3.65 & 3.21 & 3.82 & 0.81 & 0.67 & 0.63 & 1.51 & 1.2 & 1.32 \\
\hline
\end{tabular}

Table (5): Effect of irradiation and different mineral fertilizer levels on the weight of 100 seeds (g), Shelling (\%), Pod yields (kg/ fad.).

\begin{tabular}{|c|c|c|c|c|c|c|c|c|c|}
\hline \multirow{2}{*}{ Main effects } & \multicolumn{3}{|c|}{ Weight of 100 seeds (g) } & \multicolumn{3}{|c|}{ Shelling (\%) } & \multicolumn{3}{|c|}{ Pod yields (kg/ fad.) } \\
\hline & 2009 & 2010 & Combined & 2009 & 2010 & Combined & 2009 & 2010 & Combined \\
\hline \multicolumn{10}{|c|}{\begin{tabular}{|l|l} 
Gamma irradiation (Gy) \\
\end{tabular}} \\
\hline $\mathbf{0}$ & 72.28 & 73.01 & 72.65 & 58.81 & 61.24 & 60.03 & 955.18 & 1009.46 & 982.32 \\
\hline $\mathbf{1 0}$ & 77.49 & 78.82 & 78.16 & 64.87 & 67.39 & 66.13 & 1046.59 & 1117.27 & 1081.93 \\
\hline 20 & 80.96 & 81.74 & 81.35 & 69.97 & 71.91 & 70.94 & 1092.82 & 1154.07 & 1123.45 \\
\hline 30 & 82.54 & 83.36 & 82.95 & 75.04 & 76.90 & 75.97 & 1199.59 & 1272.04 & 1235.82 \\
\hline LSD (5\%) & 2.39 & 2.03 & 3.30 & 5.36 & 5.54 & 5.44 & 44.50 & 35.50 & 36.50 \\
\hline \multicolumn{10}{|c|}{ Nitrogen fertilizer (Kg N/ fad.) } \\
\hline 30 & 76.72 & 77.6 & 77.16 & 64.82 & 66.15 & 65.49 & 1002.47 & 1056.40 & 1029.44 \\
\hline 60 & 79.9 & 80.88 & 80.39 & 69.53 & 72.55 & 71.04 & 1144.62 & 1220.02 & 1182.32 \\
\hline $\operatorname{LSD}(5 \%)$ & 2.31 & 2.16 & 2.52 & 2.73 & 2.86 & 2.63 & 62.3 & 74.13 & 94.07 \\
\hline \multicolumn{10}{|c|}{ Phosphorus and potassium fertilizers (Kg/ fad.) } \\
\hline $15.5 \mathrm{P}_{2} \mathrm{O}_{5}+24 \mathrm{~K}_{2} \mathrm{O}$ & 72.96 & 73.28 & 73.12 & 60.05 & 60.75 & 60.40 & 898.11 & 979.11 & 938.61 \\
\hline $15.5 \mathrm{P}_{2} \mathrm{O}_{5}+48 \mathrm{~K}_{2} \mathrm{O}$ & 76.98 & 78.2 & 77.59 & 65.82 & 69.14 & 67.48 & 1057.17 & 1112.52 & 1084.85 \\
\hline $31 \mathrm{P}_{2} \mathrm{O}_{5}+24 \mathrm{~K}_{2} \mathrm{O}$ & 80.46 & 81.18 & 80.82 & 69.08 & 72.32 & 70.70 & 1124.35 & 1172.47 & 1148.41 \\
\hline $31 \mathrm{P}_{2} \mathrm{O}_{5}+48 \mathrm{~K}_{2} \mathrm{O}$ & 82.87 & 84.32 & 83.60 & 73.77 & 75.26 & 74.52 & 1214.56 & 1288.76 & 1251.66 \\
\hline $\operatorname{LSD}(5 \%)$ & 1.21 & 1.16 & 1.42 & 1.65 & 1.84 & 1.73 & 62.52 & 43.06 & 52.93 \\
\hline
\end{tabular}


Groundnut (Arachis hypogaea L.) growth and yield responses to seed irradiation and ....

Table (6): Effect of irradiation and different mineral fertilizer levels on seed yield (kg/ Fed), straw yield (ton/ fad.) and biological yield (ton/ fad.).

\begin{tabular}{|c|c|c|c|c|c|c|c|c|c|}
\hline \multirow{2}{*}{$\begin{array}{c}\text { Main effects and } \\
\text { interactions }\end{array}$} & \multicolumn{3}{|c|}{ Seed yield (Kg/ fad.) } & \multicolumn{3}{|c|}{ Straw yield (ton/ fad.) } & \multicolumn{3}{|c|}{ Biological yield (ton/ fad.) } \\
\hline & 2009 & 2010 & Combined & 2009 & 2010 & Combined & 2009 & 2010 & Combined \\
\hline \multicolumn{10}{|c|}{ Gamma irradiation (Gy) } \\
\hline $\mathbf{0}$ & 780.38 & 795.76 & 788.07 & 1.33 & 1.40 & 1.37 & 2.11 & 2.20 & 2.16 \\
\hline 10 & 855.06 & 880.75 & 867.91 & 1.47 & 1.53 & 1.50 & 2.33 & 2.41 & 2.37 \\
\hline 20 & 892.83 & 909.76 & 901.30 & 1.52 & 1.60 & 1.56 & 2.41 & 2.51 & 2.46 \\
\hline 30 & 980.06 & 1002.75 & 991.41 & 1.67 & 1.75 & 1.71 & 2.65 & 2.75 & 2.70 \\
\hline $\operatorname{LSD}(5 \%)$ & 28.3 & 23.4 & 21.5 & 0.11 & 0.09 & 0.1 & 0.18 & 0.15 & 0.13 \\
\hline \multicolumn{10}{|c|}{ Nitrogen fertilizer (Kg N/ fad.) } \\
\hline 30 & 819.01 & 832.76 & 825.89 & 1.39 & 1.47 & 1.43 & 2.21 & 2.30 & 2.26 \\
\hline 60 & 935.15 & 961.75 & 948.45 & 1.61 & 1.67 & 1.64 & 2.55 & 2.63 & 2.59 \\
\hline $\operatorname{LSD}(5 \%)$ & 39.54 & 41.31 & 39.03 & 0.11 & 0.13 & 0.11 & 0.21 & 0.19 & 0.17 \\
\hline \multicolumn{10}{|c|}{ Phosphorus and potassium fertilizers ( $\mathrm{Kg} / \mathrm{fad})}$. \\
\hline $15.5 \mathrm{P}_{2} \mathrm{O}_{5}+24 \mathrm{~K}_{2} \mathrm{O}$ & 733.75 & 771.84 & 752.80 & 1.29 & 1.31 & 1.30 & 2.02 & 2.08 & 2.05 \\
\hline $15.5 \mathrm{P}_{2} \mathrm{O}_{5}+48 \mathrm{~K}_{2} \mathrm{O}$ & 863.70 & 877.00 & 870.35 & 1.46 & 1.55 & 1.51 & 2.32 & 2.43 & 2.38 \\
\hline $31 \mathrm{P}_{2} \mathrm{O}_{5}+24 \mathrm{~K}_{2} \mathrm{O}$ & 918.59 & 924.26 & 921.43 & 1.54 & 1.64 & 1.59 & 2.46 & 2.56 & 2.51 \\
\hline $31 \mathrm{P}_{2} \mathrm{O}_{5}+48 \mathrm{~K}_{2} \mathrm{O}$ & 992.29 & 1015.93 & 1004.11 & 1.70 & 1.78 & 1.74 & 2.69 & 2.80 & 2.75 \\
\hline $\operatorname{LSD}(5 \%)$ & 46.31 & 44.11 & 45.45 & 0.12 & 0.11 & 0.08 & 0.21 & 0.17 & 0.15 \\
\hline
\end{tabular}

Table (7): Effect of irradiation and different mineral fertilizer levels on seed oil content (\%), oil yield (Kg/ fad.) and protein content $(\%)$.

\begin{tabular}{|c|c|c|c|c|c|c|c|c|c|}
\hline \multirow{2}{*}{$\begin{array}{l}\text { Main effects and } \\
\text { interactions }\end{array}$} & \multicolumn{3}{|c|}{ Seed oil content (\%) } & \multicolumn{3}{|c|}{ Oil yield (Kg/fad.) } & \multicolumn{3}{|c|}{ Protein content $(\%)$} \\
\hline & 2009 & 2010 & Combined & 2009 & 2010 & Combined & 2009 & 2010 & Combined \\
\hline \multicolumn{10}{|c|}{ Gamma irradiation (Gy) } \\
\hline $\mathbf{0}$ & 44.66 & 46.11 & 45.39 & 341.68 & 363.29 & 352.49 & 24.05 & 24.2 & 24.13 \\
\hline 10 & 45.53 & 46.53 & 46.03 & 381.68 & 405.76 & 393.72 & 24.31 & 24.51 & 24.41 \\
\hline 20 & 45.88 & 46.6 & 46.24 & 401.60 & 419.75 & 410.68 & 24.82 & 24.92 & 24.87 \\
\hline 30 & 45.96 & 46.96 & 46.46 & 441.60 & 466.23 & 453.92 & 24.92 & 25.32 & 25.12 \\
\hline $\operatorname{LSD}(5 \%)$ & 0.33 & 0.28 & 0.31 & 13.93 & 17.21 & 19.36 & $\mathrm{NS}$ & $\mathrm{NS}$ & NS \\
\hline \multicolumn{10}{|c|}{ Nitrogen fertilizer (Kg N/ fad.) } \\
\hline 30 & 44.59 & 45.16 & 44.88 & 358.04 & 372.35 & 365.20 & 22.87 & 22.99 & 22.93 \\
\hline 60 & 46.4 & 47.96 & 47.18 & 425.40 & 456.69 & 441.05 & 26.18 & 26.48 & 26.33 \\
\hline $\operatorname{LSD}(5 \%)$ & 0.83 & 0.63 & 0.21 & 27.01 & 24.11 & 22.76 & 0.73 & 0.56 & 0.91 \\
\hline \multicolumn{10}{|c|}{ Phosphorus and potassium fertilizers ( $\mathrm{Kg} /$ fad.) } \\
\hline $15.5 \mathrm{P}_{2} \mathrm{O}_{5}+24 \mathrm{~K}_{2} \mathrm{O}$ & 41.64 & 42.76 & 42.20 & 299.54 & 326.77 & 313.16 & 23.52 & 23.73 & 23.63 \\
\hline $15.5 \mathrm{P}_{2} \mathrm{O}_{5}+48 \mathrm{~K}_{2} \mathrm{O}$ & 44.08 & 45.26 & 44.67 & 373.25 & 393.00 & 383.13 & 24.4 & 24.62 & 24.51 \\
\hline $31 \mathrm{P}_{2} \mathrm{O}_{5}+24 \mathrm{~K}_{2} \mathrm{O}$ & 46.76 & 47.72 & 47.24 & 421.11 & 436.69 & 428.90 & 24.74 & 24.96 & 24.85 \\
\hline $31 \mathrm{P}_{2} \mathrm{O}_{5}+48 \mathrm{~K}_{2} \mathrm{O}$ & 49.56 & 50.46 & 50.01 & 482.14 & 507.56 & 494.85 & 25.42 & 25.62 & 25.52 \\
\hline $\operatorname{LSD}(5 \%)$ & 1.51 & 1.11 & 1.03 & 23.11 & 27.21 & 23.76 & NS & NS & NS \\
\hline
\end{tabular}

\section{References}

[1]. Kabir, R., S. Yeasmin, A.K.M.M. Islam and Md. A. Sarkar, 2013. Effect of Phosphorus, Calcium and Boron on the Growth and Yield of Groundnut (Arachis hypogea L.). Inter. J. Bio-Sci. Bio-Technol., 5 (3): 51- 60.

[2]. Lourduraj, A.C., 1999. Nutrient management in groundnut (Arachis hypogaea L.) cultivation - A review". Agric. Res. Rev., 20: 1420.

[3]. Asiedu, E.A., A.J.G. Vangastel and B.R. Gregg, 2000. Extension agent's technical crop guidelines for assisting seed producers in Ghana.

[4]. Brady, N.C. and R .R. Well, 2002. The nature and properties of soils, 13th Ed. Pearson Education (Singapore) Pvt. Ltd. Indian branch.

[5]. Aparna, M., A. Chaturvedi, M. Sreedhar., D.P. Kumar, P. Venu-Babu and R.K. Singhal, 2013. Impact of Gamma Rays on the Seed Germination and Seedling Parameters of Groundnut (Arachis Hypogaea L.). Asian J. Exp. Biol. Sci., 4 (1): 61 - 68.

[6]. Lukanda, L.T., A.K. Mbuyi, K.K.C. Nkongolo and R.V. Kizungu, 2013. Effect of gamma irradiation on morpho-agronomic characteristics of groundnut (Arachis hypogaea L.). Amer. J. Pl. Sci., 4: 2186-2192.

[7]. Johanson,R.E. 1967.Comparison of methods for estimating cotton leaf area. Agron.J.59:493-494

[8]. 1Radford,P.J. 1967.Growth analyses formula their use and abuse. Crop sci.,7(3):134-135

[9]. AOAC (2002). Official Methods of Analysis.Association of fficial Analytical, Arlington,Virgina, USA

[10]. Gomez, K.A. and A.A. Gomez, 1984. Dtatistical Procedures for Agricultural Research. John Wiley and sons, New York, USA.

[11]. Salve, Y.V. and B.S. Gunjal, 2011. Effect of different levels of phosphorus and potassium on summer groundnut (Arachis hypogaea L.). Inter. J. Agric. Sci., 7 (2): 352-355. 
[12]. Gobarah, M.E., M.H. Mohamed and M.M. Tawfik, 2006. Effect of phsphorus fertilizer and foliar spraying with zinc on growth, yield and quality of groundnut under reclaimed sandy soils. J.Appl. Sci. Res.,2 (8): 491- 496.

[13]. Shiyam, J.O., 2010. Growth and Yield Response of Groundnut (Arachis hypogaea L.) to Plant Densities and Phosphorus on an Ultisol in Southeastern Nigeria. Libyan Agric. Res. Cen. J. Intl., 1 (4): 211-214.

[14]. Sharma, B.M. and J.S.P. Yadav, 1997. Availability of phosphorus to grain as influenced by phosphatic fertilization and irrigation regimes. Ind. J. Agric. Sci., 46: 205-210.

[15]. Rahman, M.A., 2006. Effect of Calcium and Bradyrhizobium inoculation of the Growth, Yield and quality of groundnut (Arachis hypogaea L.). Bangladesh J. Sci. Indust.Res., 41: 181-188.

[16]. Aparna, B.L., B.L. Pareek, P.S.Rathore and A. Kumawat, 2013. Effect of integrated nutrient management on productivity of groundnut (Arachis hypogaea L.) in arid western Rajastham. Agriculture of Sustainable Development, 1: 11- 14.

[17]. Thimmaiah, S. K., P. Mahadevu, K.N. Srinivasappa and A.N. Shankra, (1998). Effect of gamma irradiation on seed germination and seedling vigor in Cowpea. J. Nuc. Agric. Biol. 27(2): 142-145.

[18]. Kon, E., O.H. Ahmed, S. Saamin and N.M. Majid, (2007). Gamma Radiosensitivity Study on Long Bean (Vigna sesquipedalis). Amer. J. Appl. Sci., 4(12): 1090-1093.

[19]. Ramachandran, M. and J.V. Goud, 1983. Mutagenesis in safflower (Carthamus tinctorius). I Differential radiosensitivity. Genetic Agraria., 37: 309-18

[20]. Kiong, A., A.L. Pick, G.S.H. Lai and A.R. Harun, (2008). Physiological responses of Orthosiphon stamineus plantlets to gamma irradiation. American-Eurasian J. Sust. Agric., 2(2): 135-149

[21]. Shakoor A., M.A. Haq and M. Sadiq, (1978). Induced genetic variability in M2 and evaluation of promising mutant lines in M4 generation of mung bean. Pakistan J. Agric. Sci., 15 (1-2): 1-6.

[22]. Pitirmovae, M.A., 1979. Effect of Gamma Rays and Mutagens on Barley Seeds. Fiziol. Res., 6: 127-131

[23]. Hanan, H. L., M. A. Abdalla and S. A. Farag, 2011. Radio- Stimulation of Phytohormons and Bioactive Components of Coriander Seedlings. Turkish J.Biochem., 36 (3): 230-236

[24]. Ibrahim, S.A. and M.E. Eleiwa, 2008. Response of groundnut (Arachis hypogaea L.) plants to foliar feeding with some organic manure extracts under different levels of NPK fertilizers. World J. Agric. Sci., 4 (2): 140- 148.

[25]. Nasr- Alla, A.E. A.A. Osman and F.K.G. Soliman, 1998. Effect of increased phosphorus and potassium or sulfur application in their different combinations on yield, yield components and chemical composition of peanut in newly reclaimed sandy soil. Zagazig J. Agric. Res., 25 (3): 557- 579

[26]. El- Far, I.A. and B.R. Ramadan, 2000. Response of yield, yield components and seed quality of peanut to plant density and PK fertilization in sandy calcareous soil. Proc. 9th Conf. Agron. Minufiya Univ., 1- 2 Sept., 453- 466.

[27]. Laxminarayana, K., 2004. Effect of organic and inorganic manures on yield and nutrient uptake of groundnut (Arachis hypogaea L.) in ultisols of Mizoran. J. Oil Seeds Res., 21 (2): 280- 283.

[28]. Hossain, M. A., A. Hamid and S. Nasreen, 2007. Effect of nitrogen and phosphorus fertilizer on N/P uptake and yield performance of groundnut (Arachis hypogaea L.). J. Agric. Res. 45(2): 119- 127.

[29]. Patra, A.K., R.C. Samui, S.K. Tripethy, S.C. Mohhapatr and M.K. Nanoda, 1995. Physiological basis of yield variation in Kharif groundnut as influenced by variety, potassium and planting methods. Indian J. Agric., 38: 233- 238.

[30]. Mudibu, J., K.K. Nkongolo, A. Kalonji-Mbuyi and R. Kizungu, 2010. Effect of Gamma Irradiation on Morpho-Ag- ronomic Characteristics of Soybeans (Glycine max L.). Amer. J. Pl. Sci., 3 (3): 331-337.

[31]. Udom, G.N., F. Babatunde, S. Mustapha and B.I. Ahmed, 2003. Nodulation, growth and pod yield of groundnut under six inter cropping systems In. Esu, I.E, Amalu, U.C., Oko B.F.D. and Asumugha, G.N. (Eds.). Agriculture: The Bedrock of an Enduring Democracy. pp: 144-150. Proceedings of the 13th Annual Conference of the Agricultural Society of Nigeria, held at the University of Calabar, Cross River State, November 16-20, 2003.

[32]. Malavolta, E., G.C. Vitti and S.A. Oliveira, 1997. Avaliacao do estado nutricional das plantas. In: principios e aplicac, es, 2 nd ed. Potafos, Piracicaba, p. 319.

[33]. Burkhart L. and E. R. Collins, 1941. Mineral nutrient in peanut plant growth. Proceedings of Soil Science Society of America, 6: 272- 280 .

[34]. Rogério, F., T.R.B. da Silva, J.I. dos Santos and J.P. Poletine, 2013. Phosphorus fertilization influences grain yield and oil content in crambe. Industrial Crops and Products, 41: 266-268.

[35]. El-Habbasha, S.F., A.A. Kandil, N.S. Abu-Hagaza, A.K. Abd El-Haleem, M.A. Khalafallah and T.G. Behairy, 2005. Effect of phosphorus levels and some bio fertilizers on dry matter, yield and yield attributes of groundnut. Bull. Fac. Agric., Cairo Univ, 56: 237-252.

[36]. Sanker, A.H., P.R. Reddy and I.V.S. Rao, 1984. Nodulation and nitrogen fixation in groundnut as affected by seed size and phosphorus. Legume res., 7: 1- 5.

[37]. Marschner, H., 1986. Mineral nutrition of higher plants. Institute of Plant Nutrition, University of Hohenheim, F.R.G. Academic Press, Publisher Jovanvich, London.

[38]. More, K.A., C.B. Gaikwad and D.V. Dahat, 2002. Effect of N, P, Rhizobium and phosphate solublizing bacteria on groundnut. J. Mah. Agrl. Univ., 27: 202-204. 